Archived version from NCDOCKS Institutional Repository http://libres.uncg.edu/ir/asu/

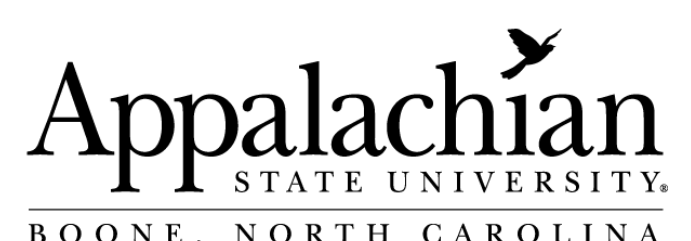

\title{
Confronting Violence in Postwar Guatemala: An Introduction
}

Authors:

Timothy J. Smith, Thomas A. Offit

No Abstract

Timothy J. Smith, Thomas A. Offit (2010) "Confronting Violence in Postwar

Guatemala: An Introduction" Journal of Latin American and Caribbean Anthropology 15(1):1-15 Version of Record available @ (DOI: 10.1111/j.1935-4940.2010.01060.x) 


\section{Confronting Violence in Postwar Guatemala: An Introduction}

By

Timothy J. Smith

A P P A L A CH A N STA TE UN IVER S T Y

Thomas A. Offit

B A Y LOR UN I V ER SITY

A Strange Yet Familiar Violence in Postwar Guatemala

ON IO MAY 2009, RODRIGO ROSENBERG, a prominent attorney in Guatemala City, was shot in the head and killed while riding his bike. Days before his murder, Rosenberg videotaped an 18-minute message, subsequently circulated widely in Guatemala and internationally, in which he stated that should he be killed in the near future, the intellectual authors of the crime would be standing president Alvaro Colom and his wife, Sandra Torres. Their motive would be retribution, specifically for Rosenberg's representation of another recently murdered member of the Guatemala City elite, the businessman Khalil Musa. In the videotape, Rosenberg states that Musa was murdered because of the information he was about to release, which clearly showed the president's links to organized crime and drug trafficking. Rosenberg said he made the recording because he feared that Colom and his associates would not stop at killing Khalil Musa.

The killing never stops in Guatemala. More than a decade after the 1996 Peace Accords were signed, which ended 36 years of civil war, homicide rates rival those during the war years. Progress on all fronts seems minimal at best; economic and social gaps between the wealthy and the poor are among the world's worst. Falling 
coffee and sugar prices on the global market, chronically high underemployment in combination with refugee repatriation and the demobilization of government and guerrilla armed forces, and a drop in tourism revenue because of a generally poor global economy and fear of terrorism, all contribute to Guatemala's dire economic, political, and social conditions. Vigilantism, organized crime, and politically motivated killings are part of daily life.

Security concerns dominate political and everyday arenas and are the main indicators for continued violence. Some communities counter this violence with more violence; some merely blame the government and advocate strongarm ( mano dura) regimes-all of which take place at the cost of limited civil rights and possible remilitarization of the state. In the aftermath of mass violence, genocide, and retribution, Guatemala is confronting a postwar period of continued violence, characterized by a culture of fear and tenuous trust between citizens and the state.

Levels of political violence remain high: Rosenberg's assassination is only the most recent manifestation of a "peacetime" trend that began with the assassination of Bishop Juan Gerardi in 1998 and the search to bring his murderers to justice; continuing through Jennifer Harbury's hunger strike and legal actions to reveal the actors responsible for murdering her husband, Efrain Bamaca Velasquez; the unsatisfactory trial of the architects of Myrna Mack's assassination; the murder of four Central American congressmen in 2007, and the subsequent murder of their alleged killers while in a maximum security jail; not to mention the continued discoveries and excavations of clandestine cemeteries. Non-political, or perhaps put more honestly, everyday violence now inundates Guatemalan citizens of all classes, as evidenced by newspaper headlines detailing daily kidnappings, murders, gang violence, and armed assaults throughout the nation.

To make matters worse, Guatemalans can hardly rely upon the police or the justice system for help. Trust in and reliance upon the police is frustrated by the trading of milita ry uniforms for those of the PNC (National Civil Police). In some cases, assailants in violent crimes have worn full or partial police uniforms and have used vehicles that resemble police transport, indicating that some elements of the police might be involved. A Human Rights report distributed by the U.S. Department of State (2005) comments, "The UN Mission in Guatemala (MINUGUA) reported several cases in which military and police officials were responsible for killings, usually for criminal motives. During the year, the PNC Office of Professional Responsibility (ORP) investigated 51 reports of police involvement in killings."

Moreover, Guatemala suffers from an inept justice system incapable of handling either the convictions of major perpetrators of violence or the handing over of convicts to correctional facilities (e.g., one of the major jails, Pavoncito, was controlled by inmates for nearly two years before a bloody attempt by the police to 
take back control). According to the U.S. Depart ment of State's Background Note [on] Guatemala (2009a): "Violent criminal activity continues to be a problem in Guatemala, including murder, rape, and armed assaults against foreigners. The police force is inexperienced and under-funded, and the judicial system is weak, overworked, and inefficient. Well-armed criminals know there is little chance they will be caught or punished." An apt summary of the current plight of peacetime Guatemala is presented in the U.S. State Department's 2008 Country Report on Hu man Rights Practices, Guatemala (2008):

Human rights and societal problems included the government's failure to investigate and punish unlawful killings committed by members of the security forces; widespread societal violence, including numerous killings; corruption and substantial inadequacies in the police and judicial sectors; police involvement in kidnappings; impunity for criminal activity; harsh and dangerous prison conditions; arbitrary arrest and detention; failure of the judicial system to ensure full and timely investigations and fair trials; failure to protect judicial sector officials, witnesses, and civil society representatives from intimidation; threats and intimidation against journalists; discrimination and violence against women; trafficking in persons; discrimination against indigenous communities; discrimination and violence against gay, transvestite, and transgender persons; and ineffective enforcement of labor laws, including child labor provisions.

The United States has recently signed a letter of agreement with Guatemala to provide funding to help combat organized crime and drug trafficking ( U.S. Department of State 2009b). A small part of the US\$16,000,000 total pledge, US\$550,000, is specifically earmarked to strengthen the International Commission against Impunity in Guatemala (CICIG), the very commission that has responded to the thousands of protestors who have flooded the streets of Guatemala City in response to the assassination of Rosenberg by promising a full investigation of both the murder and Rosenberg's accusation.

\section{An Anthropology of (Post)War Guatemala}

In 2002, a double panel was held at the annual meeting of the American Anthropological Association. It focused upon the successes and failures of the Guatemalan Peace Accords; two edited volumes resulted, which attempt to recapture the academic recipe for garnering the international community's attention, as Robert Carmack's edited volume did during the armed conflict (1988). These two volumes highlight what may be called a "new" violence in Guatemala, one that is wrought with a failing economy, a rise in narco-trafficking, gang violence, inept and corrupt 
juridical institutions, political violence, and the failures of a morally bankrupt government (Little and Smith 2009; Nelson and McAllister 2010). These works mark an attempt by anthropologists to evaluate what has been accomplished to aid in the healing of these memories and effectively deal with the horrors of war, fo- cusing upon the 10 years immediately after the end of the conflict. These scholars, in addition to bringing depth to the alarming statistics pointing to a rise in poverty, gang violence, violence against women, lynchings, drug trafficking, kidnapping for ransom and retribution, and squandering of reconstruction funds by the Portillo Administration, led them to the conclusion that a new form of struct ural violence existed in Guatemala. By all accounts, it appeared that little had changed since the end of the war, save perhaps the trading of military uniforms for those of the PNC, and indiscriminate highway robbers for an end to massacres. Anthropologists working in Guatemala have been guided by new analytical interests to focus on structural violence, and on gaining an understanding of how it appeared, statis- tically, that Guatemala was now more dangerous than it had been IO years earlier.

Despite the surfacing of new forms of violence and the growing dangerousness of Guatemala, the 36 years of violent conflict which marked the second half of the 20th century in Guatemala have not disappeared from either the memories of Guatemalans or the attentions of anthropologists, many of whom continue to struggle with analytical frameworks (such as social suffering, structural violence, memory and trauma, neoliberal policy failure, truth and reconciliation) that would allow an understanding of postwar Guatemala. In fact, many of our new frameworks to understand the violence of today are informed by our analyses and writings about the armed conflict over the past 14 years. For the purposes of underwriting the articles gathered here, we want to provide a brief overview of the major scholarship by foreign anthropologists in Guatemala since 1996, and call attention to what we see as shifting genres of dealing with the violence of both the armed conflict and the postwar era. While this is certainly not an exhaustive list (we look specifically at scholarship in book-length form that speak to audiences external to the country), we want to delineate what we see as a swinging pendulum of literature, which moves across the topical fields of memory and trauma, peace and reconciliation, and the rise of structural violence in the postwar era.

\section{Multiculturalism}

$\mathrm{Nu}$ merous books on the rise of multiculturalism and the growing public face and influence of indigenous activism have garnered the attention of anthropologists focused upon Guatemala, particularly centered upon the so-called pan-Maya Movement. In doing so, anthropologists who have focused on this movement, which itself was shaped and born out of the violence, have dealt more with issues of 
cultural construction, the promotion of Maya language and identity, and indigenous intellectuals as they negotiate the muddy terrain of postwar political machinery and multiculturalism as part of the reconciliation process (Fischer and Brown 1996; Warren 1998; Nelson 1999). While the first round of ethnographies dealing with the "rise" of indigenous activism earmarked the 1970s as a time of cultural activist awakenings, which expanded in the 1990s, Greg Grandin's seminal work on the history of blood, race, and nation (as they pertained to indigenous consciousness, i.e., the pan-Maya Movement) examined liberal reforms of the late 19th century as having rooted and shaped the indigenous agency and cultural constructions championed after the armed conflict (2000). Another foreign scholar who focused upon the pan-Maya Movement was Edward Fischer, who moved beyond the historical and descriptive approaches in describing the development of indigenous activism (2001). His ethnography brought an economic and global perspective to the cultural logics and transnational networks involved in shaping indigenous agendas, and blurred the lines between change/continuity, constructivist/essentialist arguments. This approach toward bridging the divide between the local and global, in addition to providing a detailed communitylocated ethnography, would foreshadow a later round of ethnographies in the opening decade of the 21 st century. Finally, two other works that would add to the discussion of the origins and impact of indigenous activism on Guatemalan postwar society came, ironically (in the sense that, with the exception of Fischer and Brown 1996, non-Guatemalans were writing about the pan-Maya Movement abroad), from an indigenous anthropologist (Montejo 2005) and from a scholar writing about nonindigenous or ladino identity in the wake of neoliberal multiculturalism (Hale 2006).

\section{Memory, Violence, and Suffering}

Almost immediately following the signing of the Peace Accords in 1996, scholarship on postwar Guatemala began to focus upon the ghosts of war and open wounds. Anthropological works highlighted the atrocities that had been committed by the army, its state-sponsored paramilitary organizations and their allied mercenaries, as well as the guerillas. In particular, ethnography turned its attention to genocide and unearthed the hundreds if not thousands of massacres that had been perpetrated against the largely indigenous population of the western highlands. When two reports were published, bringing light to the memorias and testimonios (CEH and REHM!) shortly thereafter, expert witnesses, international observers and analysts, and anthropologists increased their efforts to give voice to those who had suffered during the worst years of la violencia, from 1978 to 1982. It was a time when solidarity and sympathy drove ethnographers to ask: what had happened on the ground in the communities, who was responsible, and how had 
these years of terror affected and influenced what would come to be a prolonged attempt at reconciliation? Show trials and impunity continued to plague the vic- tims of the war as the still frail and "spooked" justice system failed to convict the authors of the violence. All the while, forensic anthropologists working with com- munities most affected by the violence continued to unearth the mass graves and rebury the dead.

In the 14 years since the end of the armed conflict, a number of book-length pieces have appeared outside Guatemala, dealing specifically with its aftermath. These range from ethnographies to detailed investigations into what had occurred during the conflict, and the impact of the atrocities committed by the Guatemalan military and the guerillas. Some make use of testimonials such as those collected by the Catholic Archdiocese's REMHI project (REMHI 1998) and the Commission for Historical Clarification (Comision para el Esclarecimiento, CEH 1999) by providing an anthropological narrative and analysis to uncover how communities had suffered during the violence as well as how victims were dealing with the hor- rors of war as both catharsis and collective memory (Carlsen 1997; Zur 1998; Green 1999). Others chose to move immediately toward uncovering the involvement of the United States and its intelligence/military apparat us' involvement with the Guatemalan military, to shed light upon the authorship of counterinsurgency tactics on the part of the Guatemalan state (Harbury 1997; Schirmer 1999). This would be revisited later in the postwar era with other notable works (Grandin 2004; Saxon 2007).

In a foreshadowing of future attempts, Victor Montejo, himself forced to flee the violence, studied the atrocities enacted on the ground and how those violent memories shaped Guatemalan refugees' identity and understanding of the conflict in Mexico (1999). Virginia Garrard-Burnett's detailed account of the rise and im- pact of Protestantism in Guatemala was a precursor to future studies in that she demonstrated how a transnational/global network effectively shaped communities and their members (the global to local), as well as their relationship to the state (1998). Finally, in what could be viewed as one of the most significant debates to engage American anthropology in decades, David Stoll published his critique of Nobel La ureate Rigoberta Mench u's testimony ( Burgos-Debray 1983), in which he questioned the validity of some of the details from her account (1999). Although it was an extension of his earlier thesis on indigenous communities caught in the crossfire and discourse that shaped the dichotomy between armies and guerillas (1993), his so-called expose caused such a controversy and plethora of articles, editorials, and scholarly panels dedicated to the debate that Arturo Arias was able to piece together a multidisciplinary volume on the topic (2001).

At the beginning of the 21st century, with the exception of Susanne Jonas' examination of the challenges, competing agendas, and obstacles to the peace process 
(2000), scholarship was marked by a continued interest in the plight of Guatemalan Mayas, both as victims and agents for change in the postwar era. In addition to this new literature on Mayas, a n umber of ethnographies and collections returned to the issues of memory and the terror which plagued both internal and external refuges and highlighted the continuing legacy of violence shaping indigenous comm unities during the conflict (Remijnse 2003; Manz 2004; Sanford 2004; Wilkinson 2004).

Global Connections and the New Violence

Meanwhile, an alternative round of book-length scholarship surfaced outside Guatemala in which, at a time when an emergent interest in global studies was effectively displacing traditional area and community studies in U.S. universities, a global analysis was made from the ground up, both within and outside the region. The first book-length examinations of a Maya diaspora appeared which detailed the plight not only of refugees who longed to return but also of those indigenous Guatemalans born abroad and their understandings of the conflict as they negotiated the terrain of dangerous migratory routes and undocumented positions outside the country (North and Simmons 1999; Loucky and Moors 2000; Fink 2007; St0len 2007; Foxen 2008). New works also appeared which attempted to wed a growing interest in transnational markets and economies, communication networks, internal displacement, open borders, and remittances with grounded, locally informed ethnographies (Little 2004; Fischer and Benson 2006; Kahn 2006; Metz 2006; Adams and Hawkins 2007; Offit 2008; Pitarch et al. 2008; Goldin 2009; Metz et al. 2009).

While these works interweave discussions about the failed neoliberal policies of corrupt administrations, a plunging economy, and the brazen theft of international aid funds aimed at rebuilding the country, none of them deal with new forms of violence as specific topics of study. In light of the two recent volumes on the new violence (Little and Smith 2009; Nelson and McAllister 20IO), the articles collected here attempt to build upon the previous scholarship and ask us to move to the next stage of understanding and acknowledgement, to reflect upon the fact that while so much excellent work has been done to document the degree to which the conflict still looms over the hearts and minds of Guatemalans, and the new faces and types of postwar violence, we have yet to analyze adequately why these two linked phenomena have come to define Guatemala in this time of supposed peace.

For example, how is everyday violence affecting community networks and cultural traditions, leaving younger generations unwilling to balance the risk of participation with the possibility of death? Is the fear of highway robbery and the chaos that stems from economic insecurity to blame? Offit and Cook, discuss the murder of one of the most revered shamans of Momostenango on a small rural road in 2007-stabbed, shot dead, and nearly decapitated by two men. His death 
was relatively common by Guatemalan standards, yet the current wave of violence is unique in that it seems to come from, and is directed toward, all sectors of society, and as a result leaves everyone in a state of perpetual fear and imbalance. Offit and Cook's article looks at how this imbalance has threatened the existence of the traditional "Monkeys' Dance," not only by killing its sponsor, but by undermining the confidence the young male dancers have concerning the spiritual efficacy of their significant financial sacrifice in participating in the dance and therefore guaranteeing the continued support of their ancestors and the town's patron saint. As the logical inheritors of this shaman's knowledge and his cargo, dancers now must reassess their commitment to centuries' old cultural practice and belief amidst the economic and physical insecurity of neoliberal Guatemala.

While much of the everyday violence of postwar Guatemala may appear to be random or a product of "men with guns" out of work, what historical linkages are there with the past, if any? Can we bury the dead and let water pass under the bridge when the old perpetrators are living in the same communities as their victims? What if the lines between perpetrator and victim are blurred in postwar Guatemala? The article by Mentz, Mariano, and Lopez Garcia discusses the situation in the Ch'orti' area of Eastern Guatemala, which continues to be a relatively violent place. Drawing a direct connection between the war and contemporary violence is difficult, however. Rather than seeing violence spawning callousness and more violence, which is no doubt true for some individuals, one might equally find that people are less apt to rush to violence after suffering from it. Moreover, human rights campaigns like those of MINUGUA, the Catholic Church, and the Maya Movement, which promoted the civil resolution of disputes, were fairly well received by a Ch'orti' population that once considered all state authorities as threats. The police, while still ineffective and corrupt, are now more likely to pursue murderers in the rural communities than they were during the war, when the army reigned seemingly arbitrarily. A more persuasive linkage of the war to contemporary violence is a continuation of the problems that helped precipitate some Ch'orti's' involvement in the war to begin with, including pressure on the land, envy, sorcery, graft, a corrupt and inept judicial system, and ethnic dehumanization. New problems that suggest greater alienation and a deeper culture of violence are child abduction, human trafficking, and drug smuggling. The Ch'orti' area has become a theater for such criminality, and Ch'orti's are becoming involved as both victims and perpetrators.

This issue also seeks to address the apparent fear that still directs rural communities to distrust the State, even when it reaches out through aid via health promotion, disaster relief, and juridical reform. Why are legitimate attempts to reconstitute the police force met with opposition, doubt, and suspicion? Why are communities instead choosing to (in fact, feel that they must) create internal self-policing units, support networks, and outlets, which they believe best serve 
their needs? How do national and regional anxieties about violence and security merge with local concerns, conflicts, and power struggles? Burrell's article addresses migrants and migration as factors in considering postwar violence as a web of struggles with many locations, each playing into negotiations on how decisionmaking processes take place and are enacted. How are migrants at once players in new forms of violence and challengers to traditional structures of power and authority, and of community responses to them? Building on research that looked at so-called mareros (who, in fact, were returned migrants who challenged traditional authority and power structures and were thus labeled "gangsters") in Todos Santos, Burrell explores the ways in which security committees now operating in Todos Santos are viewed in the satellite communities of Todosanteros in the United States, and what kinds of discourses are informing or influencing how mi- grants view them (i.e., hu man rights, or mano d ura).

Furthermore, it might be asked how the misunderstanding of community dynamics and local histories, and the legacy of violence, lead to a misdiagnosis from international aid organizations. Are foreign aid agencies the only ones who notice both community vulnerability and resilience? Patricia Foxen discusses the state of violence and social instability that has characterized postwar Guatemala, combined with changes brought about by rapid globalization, and argues that this has created an atmosphere of chronic distress and anxiety in many indigenous communities, expressed in acute levels of trauma, fear, psychosomatic symptoms, substance abuse, and domestic violence. Given that some individuals and communities have been able to cope better than others with the disruptions of the past decades, this article seeks to determine the key subjective and cultural factors contributing to psychosocial vulnerability and resiliency among Mayan Indian women and men in Guatemala. Foxen's article explores individual and collective expressions of distress and coping among indigenous people in two highland communities. She examines the different cultural and gendered idioms and social strategies used by Maya women and men to transform various types of social suffering and violence, thus moving away from the biomedical notions of trauma and pathology and underscoring local, historically situated frameworks for meaning-making and psychosocial well-being in postwar contexts.

How, then, might these articles best express a successful merging of locally grounded ethnography with the global repercussions felt in postwar Guatemala, to bring together previous waves of research interests? Can anthropology offer a theoretically engaging analysis of international concerns on the ground without betraying the intimacies and nuances of community research, and without resorting to international frameworks? New modes of representation following the postmodern critiques of the 1980s (and those which still linger today) have brought new challenges to ethnographers both from within and outside their traditional 
audiences, and new literat ure still offers a caveat to those social scientists working in Latin America- that they be wary of continued forms of romanticization and stereotypes draped in new covert paradigms and structural essentializations, despite their political convictions and or advocacy (Mignolo 2000; Lange-Churi6n and Mendieta 2001; Volek 2002; Smith 2006).

And while we tiptoe around the minefields of representation and stereotypes, anthropologists must pay serious attention to individuals and the power they have brought themselves to their local worlds and we must ask what is at stake for both anthropology and the subject. The authors in this issue are attempting to provide an experience-oriented approach in order to construct a philosophical history and draw an understanding out of the ethnography which, according to Alan Klima, may help us to connect "mutually informative practices in a way that does not fall back on the cartographic- literalist notions of culture, space, and place" (2002:8). An ethnography of social experience attempts to focus on the individual, contradictory, and messy interaction that individuals have with their local worlds. We believe the articles in this issue do just that.

In placing cultural processes within larger global contexts, both a state-imposed and a personal identity can be seen as the result of historical events, political conflicts, and the process of globalization (Ong 1999). "State," for Aihwa Ong, does not mean a supra-sanctioned identity whereas the nation retains its classification of self-imposed identity; that is, one's identity and being are crafted on two fronts: relation to the state and relation to others within that state. Individuals receive one classification imposed upon them from outside forces, yet are able to voice and express their own conception of being. The realization of this by individuals allows them to play with their relationships to political organizations and adapt to both the real and unreal borders/constraints that appear in those relations and confrontations. While states and individuals constantly adapt to one another, their form and identities must, as a consequence of the State-and-mouse game, change, as must our concept of their relationship. Individuals constantly adapt and reframe their own political positions in order to jibe with current social and political events. Given the topics covered by these articles, and the new relationships between the State and communities that are being formed (or abandoned, in postwar Guatemala), are we witnessing a new localization of identities that seeks to circumvent the State and create new municipal-level identities around issues of self-reliance and protection?

What has allowed these new waves of violence to persist and how are they linked to the armed conflict? How are the ways in which individuals, both victims and perpetrators, choose to address postwar violence counter-productive to healing, if at all? We seek to wed the scholarship on both memory and structural violence to highlight those obstacles that prevent the wounds from closing. Have we been 
asking how the wounds may heal and the scars be someday erased when instead we should be asking how the Guatemalan body must instead be viewed as scarred from memory and how citizens are refashioning and reformulating that mutilated body for a new politics and everyday life? As we write, there are daily demonstrations of tens of thousands of Guatemalans calling specifically for an investigat ion into who is responsible for the death of Rodrigo Rosenberg, and in a far more general sense for an end to the violence. The Guatemalan populace is on the streets demanding an end to violence, impunity, and injustice, ironically enough during an epoch when such relics of the war-time era were hoped to have been on the wane.

\section{Note}

${ }^{1}$ On 12 January 2010, a special United Nations commission announced that after an 8-month investigation it concluded that Rosenberg had arranged for his own assassination. The findings suggest that he staged his murder as revenge after he could not directly implicate President Colom in the killing of Khalil Musa in May of 2009. His two accomplices remain at large, brothers Francisco Jose Valdez Paiz and Jose Estuardo Valdez Paiz.

\section{References Cited}

Adams, Walter R. and John P. Hawkins

2007 Health Care in Maya Guatemala: Confronting Medical Pluralism in a Developing Country. Norman: University of Oklahoma Press.

Arias, Arturo, ed.

200I The Rigoberta Menchu Controversy. Minneapolis: University of Minneapolis Press.

Burgos-Debray, Elisabeth

1983 Me Llamo Rigoberta Menchu y Asi Me Naci6 la Conciencia. Barcelona: Editorial Argos Vergara, S.A.

Carlsen, Robert S.

1997 The War for the Heart and Soul of a Highland Maya Town. Austin: Un iversity of Texas Press.

Carmack, Robert, ed.

1988 Harvest of Violence. The Maya Indians and the Guatemalan Crisis. Norman: University of Oklahoma Press.

Comisi6n para el Esclarecimiento (CEH)

1999 Guatemala, Memoria de/ Silencio, 12 tomos. Guatemala.

Fink, Leon

2007 The Maya of Morganton: Work and Community in the Nuevo New South. Chapel Hill: University of North Carolina Press. 
Fischer, Edward F.

2001 Cult ural Logics and Global Economies. Maya Identity in Thought and Practice. Austin: University of Texas Press.

Fischer, Edward F. and Peter B. Benson

2006 Broccoli and Desire: Global Connections and Maya Struggles in Postwar Guatemala. Palo Alto: Stanford University Press.

Fischer, Edward F. and R. McKenna Brown, eds.

1996 Maya Cultural Activism in Guatemala. Austin: University of Texas Press.

Foxen, Patricia

2008 In Search of Providence: Transnational Mayan Identities. Nashville: Vanderbilt University Press.

Garrard-Burnett, Virginia

1998 Protestantism in Guatemala. Living in the New Jerusalem. Austin: University of Texas Press.

Goldin, Liliana R.

2009 Global Maya: Work and Ideology in Rural Guatemala. Tucson: University of Arizona Press.

Grandin, Greg

2000 The Blood of Guatemala: A History of Race and Nation. Durham: Duke University Press.

2004 The Last Colonial Massacre. Chicago: University of Chicago Press.

Green, Linda

1999 Fear as a Way of Life: Mayan Widows in Rural Guatemala. New York: Columbia University Press.

Hale, Charles

2006 Mas que un indio: Racial Ambivalence and the Paradox of Neoliberal Multiculturalism in Guatemala. Santa Fe: School of American Research Press.

Harbury, Jen nifer K.

1997 Searching for Everardo: A Story of Love, War, and the CIA in Guatemala. New York: Warner Books.

Jonas, Susanne

2000 Of Centaurs and Doves: Guatemala's Peace Process. Boulder: Westview Press. Kahn, Hilary E.

2006 Seeing and Being Seen: The Q'eqchi' Maya of Livingston, Guatemala, and Beyond. Austin: University of Texas Press.

Klima, Alan

2002 The Funeral Casino: Mediation, Massacre, and Exchange with the Dead tn Thailand. Princeton: Princeton University Press. 
Lange-Ch urion, Pedro and Eduardo Mend ieta, eds.

200I Lati n America and Postmodernity: A Contem porary Reader. Am herst: Humanity Books.

Little, Walter E.

2004 Mayas in the Marketplace: Tourism, Globalization, and Cultural Identity. Austin: University of Texas Press.

Little, Walter E. and Timothy J. Smith, eds.

2009 Mayas in Postwar Guatemala: Harvest of Violence Revisited. Tuscaloosa: University of Alabama Press.

Loucky, James and Marilyn Moors, eds.

2000 The Maya Diaspora. Philadelphia: Temple University Press.

Manz, Beatriz

2004 Paradise in Ashes. A Guatemalan Journey of Courage, Terror and Hope. Berkeley: University of California Press.

Metz, Brent E.

2006 Ch'orti'-Maya Survival in Eastern Guatemala: Indigeneity $\mathrm{m}$ Transition. Albuquerque: University of New Mexico Press.

Metz, Brent E., Cameron L. McNeil and Kerry M. Hull, eds.

2009 The Ch'orti' Maya Area: Past and Present. Tallahassee: University Press of Florida.

Mignolo, Walter

2000 Local Histories/Global Designs: Coloniality, Subaltern Knowledges, and Border Thinking. Princeton: Princeton University Press.

Montejo, Victor D.

1999 Voices from Exile: Violence and Survival in Modern Maya History. Norman: University of Oklahoma Press.

2005 Maya Intellectual Renaissance: Identity, Representation, and Leadership. Austin: University of Texas Press.

Nelson, Diane M.

1999 A Finger in the Wound: Body Politics in Quincentennial Guatemala. Berkeley: University of California Press.

Nelson, Diane M. and Carlota McAllister, eds.

2010 Revisiting Guatemala's Harvest of Violence. Durham: Duke University Press.

North, Lisa and Alan Simmons, eds.

1999 Journeys of Fear: Refugee Return and National Transformation in Guatemala. Montreal: McGill-Queen's University Press.

Offit, Thomas A.

2008 Conquistadores de la Calle: Child Street Labor in Guatemala City. Austin: University of Texas Press. 
Ong, Aihwa

1999 Flexible Citizenshi p: The Cultural Logics of Transnationalism. Durham: Duke University Press.

Pitarch, Pedro, Shannon Speed and Xochitl Leyva-Solano, eds.

2008 Human Rights in the Maya Region: Global Politics, Cultural Contentions, and Moral Engagements. Durham: Duke University Press.

REMHI - Human Rights Office of the Archdiocese of Guatemala, Interdiocesan Project for the Recovery of Historical Memory.

1998 Guatemala: Nunca Mas. Guatemala City: REMHI.

Remijnse, Simone

2003 Memories of Violence. Civil Patrols and the Legacy of Conflict in Joyabaj, Guatemala. Amsterdam: Thela Latin American Series.

Sanford, Victoria

2004 Buried Secrets: Truth and Human Rights in Guatemala. New York: Palgrave Macmillian.

Saxon, Dan

2007 To Save Her Life: Disappearance, Deliverance, and the United States $m$ Guatemala. Berkeley: University of California Press.

Schirmer, Jennifer

1999 The Guatemalan Military Project. A Violence Called Democracy. Philadelphia: University of Pennsylvania Press.

Smith, Timothy J.

2006 Views From the "South": Intellectual Hegemony and Postmodernism in Latin America. Reviews in Anthropology 35( I): 61-78.

Stoll, David

1993 Betweeen Two Armies in the Ixil Towns of Guatemala. New York: Colombia University Press.

1999 Rigoberta Menchu and the Story of All Poor Guatemalans. Boulder: Westview Press.

Stolen, Kristi Anne

2007 Guatemalans in the Aftermath of Violence: The Refugees' Return. Philadelphia: University of Pennsylvania Press.

United States Department of State

2005 U.S. Department of State Country Report on Human Rights Practices 2004 - Guatemala. Electronic document, http://www.unhcr.org/refworld/ docid/4226d9932f.html, accessed February 28, 2005.

2008 Country Report on Human Rights Practices: Guatemala. Electronic document, htt p://www.state.gov/g/d rl/rls/h rrpt/2007/ I 00641.htm, accessed February 15, 2009. 
2009a Background Note: Guatemala. Electronic document, http://www.state.gov/r/ pa/ei/bgn/2045.htm, accessed February 15, 2009.

2009b U.S. Embassy to Guatemala Press Release. Electronic document, http:// guatemala.usembassy.gov/pbe20090205.html, accessed February 15, 2009.

Volek, Emil, ed.

2002 Latin America Writes Back: Postmodernity in the Periphery (An Interdisciplinary Perspective). New York: Rou tledge.

Warren, Kay

1998 Indigenous Movements and Their Critics: Pan-Maya Activism in Guatemala. Princeton: Princeton University Press.

Wilkinson, Daniel

2004 Silence on the Mountain Stories of Terror, Betrayal, and Forgetting $\mathrm{m}$ Guatemala. Durham: Duke University Press.

Zur, Judith N.

1998 Violent Memories: Mayan War Widows in Guatemala. Boulder: Westview Press. 
